\title{
ISIBINDI, creating circles of care for orphans and vulnerable children in South
}

\section{Africa: post-programme outcomes}

\author{
Maretha Visser a, Nompumelelo Zungu ${ }^{b}$, Nkateko Ndala-Magoro a \\ a Department of Psychology, University of Pretoria, Pretoria, South Africa \\ ${ }^{b}$ Human Science Research Council, Pretoria, South Africa
}

\begin{abstract}
* Maretha Visser, Department of Psychology, University of Pretoria, Pretoria, South Africa maretha.visser@up.ac.za Nompumelelo Zungu, Human Science Research Council, Pretoria, South Africa, mzungu@hsrc.ac.za Nkateko Ndala-Magoro, Department of Psychology, University of Pretoria, Pretoria, South Africa, Nkateko.NdalaMagoro@up.ac.za

${ }^{*}$ Corresponding author

Funding: The research was done by independent researchers and commissioned by PACT-SA and supported by USAID. The authors do not have conflict of interests.
\end{abstract}

\section{Abstract}

This paper presents the evaluation of post-programme outcomes of the ISIBINDI model, a communitybased intervention to promote physical and psychosocial wellbeing of orphans and vulnerable children (OVC) in South Africa. A mixed methods quasi-experimental design was used to investigate the differences between former ISIBINDI participants (18 years and older) and a control group of similar background. ISIBINDI ex-participants at 12 sites $(n=427)$ and a control group of non-participants $(n=177)$ completed a questionnaire which explored level of education and employment, psychosocial wellbeing and HIV-risk behaviour. Focus group discussions were conducted with various stakeholders. 
Ex-participants reported higher self-esteem and problem-solving abilities, family support and lower HIVrisk behaviour than the control group. High levels of unemployment especially in rural areas resulted in unemployment of out-of-school OVC which creates new forms of vulnerability. The benefits of the programme may be compromised by the lack of community resources. An effective exit strategy is needed to contribute to financial independence of OVC after exiting the programme.

Key words: Orphans and vulnerable children, community-based intervention, resource-limited community, psychosocial wellbeing, programme evaluation, post programme outcomes

Children affected and orphaned by HIVIAIDS are vulnerable as the illness and death of parents often results in loss of emotional, financial and material support (Nyberg et al., 2012; Richter et al., 2009; Sherr et al., 2014). In Africa, orphans and vulnerable children (OVC) are often cared for in extended families or child-headed households (Schenk et al., 2008) vulnerable to poverty (Chingwenya et al., 2008; Meintjes et al., 2010). Some drop out of school, experience neglect, emotional, physical and sexual abuse and higher HIV-risk compared to unaffected children (Cluver et al., 2007; 2011; Nyberg et al., 2012; Thurman et al., 2006; Watts et al., 2007). OVC experience high levels of psychological distress, including depression and multiple traumas (Cluver \& Gardner, 2007; Nyamukapa et al., 2010), mediated by parental disability, poverty and stigma (Cluver et al., 2013). Medicating factors are modifiable through OVC-interventions.

During the past decade various interventions attempted to address the diverse needs of OVC (Setswe \& Skinner, 2008). Interventions focused on strengthening families (Richter et al., 2009; Rotheram-Borus et al., 2006), building caregiver capacity (Eloff et al., 2014; Reddy et al., 2009), teacher training (Wood \& Goba, 2011), strengthening community infrastructure (Nyberg et al., 2012) and developing community volunteers as mentors (Brown et al., 2007; Schenk, 2009). Despite many OVC-interventions, there are limited evaluations of their effectiveness and no evaluations of post- 
programme outcomes (Betancourt et al., 2013; Cluver et al., 2012; King et al., 2009). This paper presents post-programme outcomes of the ISIBINDI-model implemented in South Africa.

Table 1 Components of ISIBINDI programme for OVC (NACCW, 2013).

\section{Core components}

\section{Services CYCW deliver}

Life space work in households

Create safe and caring communities

Assess children's developmental needs

Grief work and emotional support (memory boxes)

Access government and community services: education, health care, social services, birth registration, access child grants and foster care grants to alleviate poverty

Provide training and support for caregivers to strengthen families

Principles underlying services

* Child rights framework

* Family preservation

* Risk management

* Partnership model between government, CBO, NACCW and donor

* Inter-sectoral collaboration

* Network resources

\section{Additional components}

- Food gardens

- Income generation projects

- Safe parks with play equipment

- Youth life skills development

- Young men and women's empowerment for employment (bursaries, careers, job opportunities)

- Child protection programme for abused children

- Education support programme, help with homework

- Substance abuse prevention

ISIBINDI ("strong heart") is a multi-site community-based intervention for OVC developed by the National Association of Child Care Workers (NACCW) and funded through PEPFAR and Department of Social Development (DSD). Community-based organisations interested to implement the model recruit community members as child and youth care workers (CYCWs) to serve local families. NACCW provides training, supervision and mentoring to CYCWs (Scott, 2009). The core of the model is home 
visits to address the physical, educational and psychosocial needs of OVC younger than 18 years and to strengthen family bonding and community support (Allsopp, 2011; NACCW, 2013). To prepare young people to exit ISIBINDI, life skills training and career guidance are offered. Programme components of ISIBINDI (Table 1) reflect most guidelines for OVC programmes (DSD, 2005; Schenk et al., 2010; UNICEF, 2004; US PEPFAR, 2012) and respond to community needs.

This evaluation aimed to determine how the ISIBINDI-model benefitted former participants' (aged 18 years and older) psychosocial wellbeing, education and employment readiness.

\section{Methods}

A quasi-experimental post-intervention assessment was applied to investigate the differences between ISIBINDI ex-participants and a control group. Focus group discussions (FGDs) were conducted with various stakeholders. The research was approved by the Ethics Committee of the Faculty of Humanities, University of Pretoria.

Two-stage stratified cluster sampling was used to recruit ex-participants. A proportional sample of ISIBINDI-sites from each province was selected (KwaZulu-Natal (5), Eastern Cape (4), Mpumalanga (2), Gauteng (1)). Sites with large numbers of participants and implementing multiple programme components were selected. At each of the 12 sites all ex-participants 18 years and older were invited to participate, yielding a convenience sample based on availability.

For each site, a similar neighbouring community where no OVC-intervention was implemented was identified as a control group. Teachers and social workers from these communities recruited OVC 18 years and older using a snowball technique. In total 427 ex-participants (average 35 per site) and 177 control group members (average 14 per site) participated in the survey.

A self-report questionnaire (Shisana et al., 2010) was used to collect data on education, employment, psychosocial wellbeing and HIV-risk. Scales assessing family support (Department of 
Education, 2008) and resilience (Mampane, 2010) were included (Table 2). All scales were previously used with South African youth.

Table 2 Psychosocial well-being scales

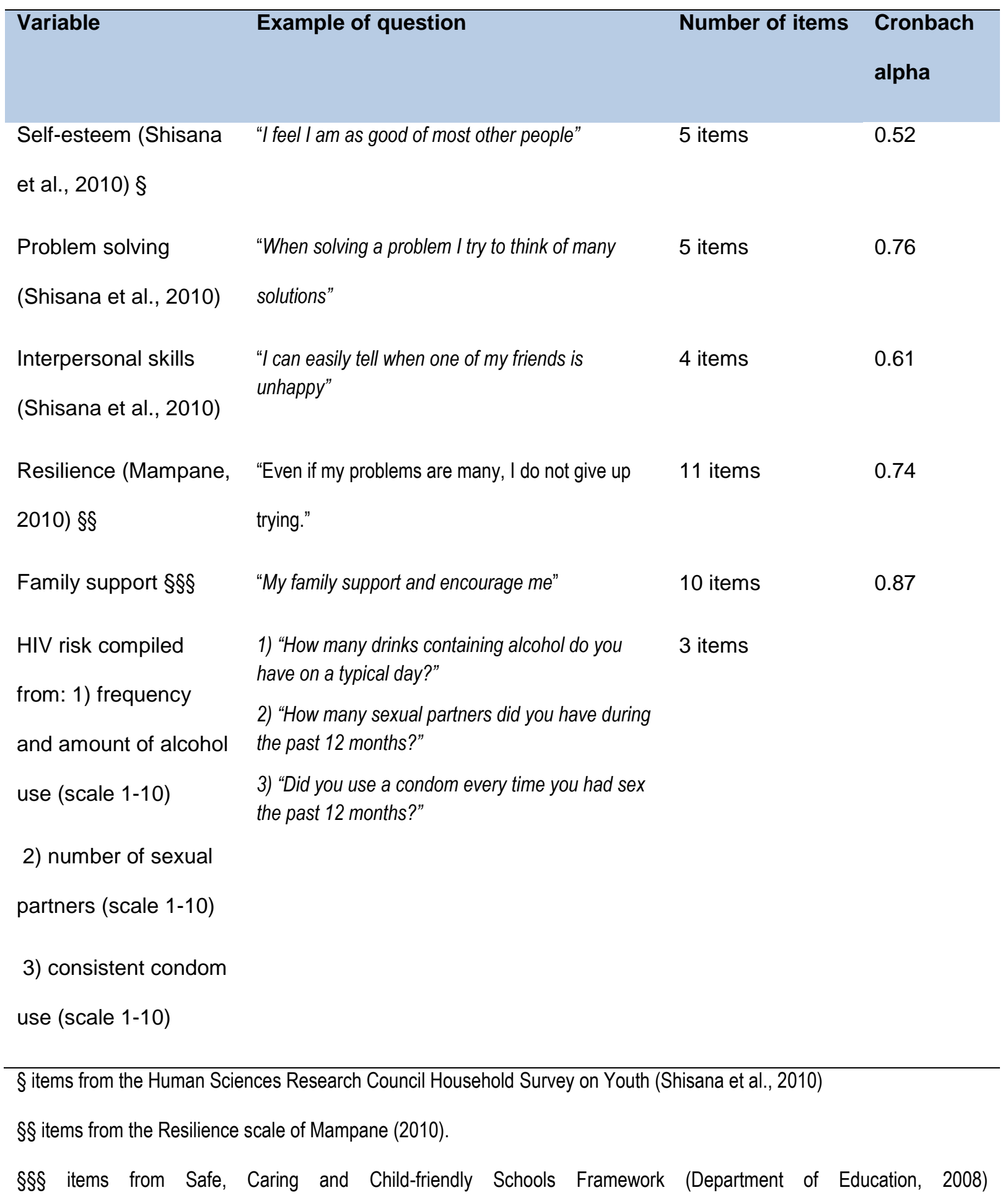


Table 3 Characteristics of participants

\begin{tabular}{|c|c|c|}
\hline & $\begin{array}{l}\text { Ex-participants } \\
(n=427)\end{array}$ & $\begin{array}{l}\text { Control } \\
(n=174)\end{array}$ \\
\hline \multicolumn{3}{|l|}{ Gender: } \\
\hline Male & $45.4 \%$ & $48.3 \%$ \\
\hline Female & $54.6 \%$ & $51.7 \%$ \\
\hline \multicolumn{3}{|l|}{ Age: } \\
\hline 18 years & $32.7 \%$ & $37.4 \%$ \\
\hline 19 years & $26.4 \%$ & $16.1 \%$ \\
\hline 20 years & $13.9 \%$ & $11.5 \%$ \\
\hline 21 years & $12.2 \%$ & $15.0 \%$ \\
\hline $22-25$ years & $14.8 \%$ & $20.0 \%$ \\
\hline \multicolumn{3}{|l|}{ Orphaned state: } \\
\hline Double orphan & $37.2 \%$ & $29.1 \%$ \\
\hline Maternal orphan & $21.3 \%$ & $19.4 \%$ \\
\hline Paternal orphan & $18.3 \%$ & $22.9 \%$ \\
\hline Non-orphan & $8.3 \%$ & $21.7 \%$ \\
\hline Unknown if double orphan $\S$ & $0.2 \%$ & $0.6 \%$ \\
\hline Unknown if single orphan $\S$ & $4.7 \%$ & $6.3 \%$ \\
\hline \multicolumn{3}{|c|}{ Main caregiver while growing up (10-18 years): } \\
\hline \multicolumn{3}{|l|}{ Mother } \\
\hline Both parents & $32.1 \%$ & $37.4 \%$ \\
\hline Grandparents & $10.8 \%$ & $13.8 \%$ \\
\hline Other family & $32.9 \%$ & $27.6 \%$ \\
\hline Siblings & $10.1 \%$ & $7.5 \%$ \\
\hline \multirow[t]{2}{*}{ Non-relatives } & $9.8 \%$ & $9.7 \%$ \\
\hline & $4.3 \%$ & $4.0 \%$ \\
\hline \multicolumn{3}{|l|}{ Level of education: } \\
\hline Grade 9 or less & $25.2 \%$ & $28.9 \%$ \\
\hline Grade $10-11$ & $43.3 \%$ & $40.5 \%$ \\
\hline Grade 12 & $24.5 \%$ & $24.9 \%$ \\
\hline Post school qualification & $7.0 \%$ & $5.7 \%$ \\
\hline \multicolumn{3}{|l|}{ Employment: } \\
\hline Attending school or studying & $64.3 \%$ & $64.5 \%$ \\
\hline Working (formal or informal) & $7.4 \%$ (out-of-school $20.8 \%$ ) & $4.1 \%$ (out-of-school $11.5 \%$ ) \\
\hline Unemployed (looking for work) & $26.8 \%$ (out-of-school $75 \%$ ) & $26.7 \%$ (out-of-school $75.4 \%$ ) \\
\hline Unemployed (not looking for work) & $1.5 \%$ (out-of-school $4.1 \%$ ) & $4.7 \%$ (out-of-school $13.1 \%$ ) \\
\hline \multicolumn{3}{|l|}{ Sources of income } \\
\hline No income & $54.5 \%$ & $71.3 \%$ \\
\hline Formal and informal earnings & $7.5 \%$ & $3.4 \%$ \\
\hline Family support & $9.9 \%$ & $5.7 \%$ \\
\hline Government grants & $26.0 \%$ & $17.8 \%$ \\
\hline Other & $2.1 \%$ & $1.8 \%$ \\
\hline
\end{tabular}

$\S$ Respondents were unsure whether their fathers were dead or alive because they did not know then or did not have contact with them 
The questionnaire was translated (and back translated) into applicable vernaculars and pilot tested. Research assistants read the questions in a group setting at each site in the vernacular of participants. Descriptive statistics and comparisons between groups (Chi-square, independent t-tests) were conducted using SPSS version 22.

At each site four FGDs were conducted with ex-participants, their caregivers, CYCWs and community stakeholders to probe stakeholders' opinion of the sustained impact of ISIBINDI. FGDs were transcribed and translated into English for thematic analysis using Atlas-ti.

\section{Results}

Participants were 18 to 25 years old. Most ex-participants (76.8\%) had lost one or both parents and grew up with grandparents $(32.9 \%)$, other family $(10.1 \%)$ or in child-headed households $(9.8 \%)$. Their level of education was generally low. Although ex-participants and control members were not matched, the groups had similar characteristics (Table 3).

The majority ex-participants (70\%) were involved in ISIBINDI for more than a year (some for five years). Most ex-participants were involved in the core programme components (Table 4) and career guidance (66\%), job empowerment and life skills training (54\%).

\section{Table 4 Exposure to programme components}

\begin{tabular}{lc}
\hline Project components ( $\mathrm{n=380)}$ & $\%$ \\
\hline Home visits and family support & 89.2 \\
\hline Personal guidance and counselling & 86.0 \\
\hline Access to a safe park & 80.9 \\
\hline Help with their study programme / tuition/ homework & 71.2 \\
\hline Help with further education and training, bursary application, job skills, career guidance & 66.7 \\
\hline Participation in life skills training, young men and women's job empowerment programme & 53.6 \\
\hline Access to health care and treatment & 48.5 \\
\hline
\end{tabular}


Psychosocial wellbeing

Ex-participants reported higher self-esteem (almost significant) and problem-solving abilities than the control group (Table 5). This is illustrated in the qualitative data: "It really helped me because it gave me guidelines as to how I should carry myself as a lady and as an orphan. I learned that I should never sell myself cheap and I should value myself, make sure that I get an education, as it will open doors for $m e^{\prime \prime}$ (Ex-participant).

Table 5 Comparison between ISIBINDI ex-participants and control group

\begin{tabular}{|c|c|c|c|c|c|}
\hline & & $\mathrm{N}$ & Mean & T value & $\begin{array}{l}P \text { value } \\
\text { (2 tailed) }\end{array}$ \\
\hline \multirow{2}{*}{ Self-esteem } & Ex-Participants & 406 & 5.01 & 1.67 & $.097^{\star}$ \\
\hline & Control & 160 & 3.82 & & \\
\hline \multirow{2}{*}{ Problem solving } & Ex-Participants & 406 & 3.97 & 3.20 & $.002^{* *}$ \\
\hline & Control & 160 & 2.26 & & \\
\hline \multirow{2}{*}{$\begin{array}{l}\text { Interpersonal } \\
\text { skills }\end{array}$} & Ex-Participants & 406 & 2.95 & -.02 & .987 \\
\hline & Control & 160 & 2.96 & & \\
\hline \multirow{2}{*}{ Resilience } & Ex-Participants & 406 & 3.43 & .79 & .433 \\
\hline & Control & 160 & 3.26 & & \\
\hline \multirow{2}{*}{ Family support } & Ex-Participants & 406 & 4.62 & 2.08 & $0.039^{\star *}$ \\
\hline & Control & 160 & 3.31 & & \\
\hline \multirow{2}{*}{ HIV- risk } & Ex-Participants & 406 & 12.9 & -2.57 & $.012^{* *}$ \\
\hline & Control & 160 & 19.7 & & \\
\hline
\end{tabular}

${ }^{*} p<0.1 ; * * p<0.05$

CYCWs promoted open communication in families to strengthen family relationships. This resulted in ex-participants reporting more family support than the control group (Table 5). A caregiver reported: "They really made a difference, because my grandchildren were able to talk to them. We were able to sit together and discuss how to deal with the situation at home". 
HIV-risk

Ex-participants reported significantly less HIV-risk behaviour than the control group (Table 5).

Specifically, males reported less binge drinking ( $12.3 \%$ vs. $30.6 \%, p<0.001)$ and females fewer unwanted pregnancies $(28.8 \%$ vs. $37 \%, p<0.1$ almost significant) than the control group.

Education and employment

Ex-participants and control members reported the same level of education (Table 3), despite ISIBINDI's focus on educational assistance. A large percentage of the sample was still in school or studying (64\%). Most out-of-school young people were unemployed looking for work (75\%). More ex-participants were employed than in the control group $(20.8 \%$ vs. $11.5 \%, p<0.05)$. They were financially somewhat advantaged (45.5\% vs. $28.7 \%$ had some income, $p<0.05)$ and more optimistic about their future opportunities than the control group $(70.5 \%$ vs. $56.3 \%, p<0.05)$. These differences may be related to ISIBINDI's focus on study support and employment readiness: "Some sell sweets and some do craftwork back at home to get some money" (Ex-participant).

Despite initiatives, scarcity of employment and livelihood opportunities particularly in rural areas jeopardises ex-participants: "There are a lot of children staying at home doing nothing. I just wish she could get a job, because no one is working in the family" (Caregiver). At age 18 child grants are terminated, leaving many OVC with no income, unless they can find employment. One ex-participant said: "I am the bread winner. I have no-one else. Even with the little income I get, it is difficult because all my siblings depend on me. I have to do everything in the house with that." This may precipitate new vulnerabilities, as young people may turn to transactional sex or crime to support themselves and their families: "Sometimes poverty plays a major role. Girls our age end up with sugar daddies who support them or move in with their boyfriends that destroy their lives" (Ex-participant). This may be reflected in $5.9 \%$ female ex-participants reporting intergenerational sex, $14.5 \%$ being victims of partner violence 
and $28.8 \%$ reporting unwanted pregnancies. The benefits of ISIBINDI may be compromised if participants cannot support themselves financially after formally exiting the programme.

\section{Discussion}

This research contributes evidence of the impact of ISIBINDI, a community-based OVC-intervention. ISIBINDI addressed many of the vulnerabilities of OVC and their families (Cluver et al., 2007; 2013; 2014). Ex-participants reported higher self-esteem and problem-solving abilities, more family support and lower HIV-risk than control members. Previous ISIBINDI evaluations also showed more adult support, but no psychological benefits (Thurman et al., 2013; 2014).

Out-of-school OVC were largely unemployed, had low levels of education and could not support themselves and their families financially, leading to new vulnerabilities. To reduce economic vulnerability, OVC-interventions should develop effective exit strategies, by linking OVC to training facilities, career opportunities or local micro-enterprises. In resource-limited areas there should be emphasis on capacity building in local organisations. OVC-interventions should ensure the wellbeing of OVC even after exiting the programme to reduce vulnerability and strengthen communities.

\section{Limitations}

A quasi-experimental post-intervention design was used, as no baseline data was available. Therefore, differences cannot be attributed directly to the intervention. Participants were not randomly selected, but through availability. Self-reporting of controversial behaviour should be interpreted with care; patterns of over- and underreporting may influence the quality of the data (Hewett et al., 2003). Some scales (like the self-esteem scale) reflected low reliability. 


\section{Conclusion}

The evaluation found that the ISIBINDI-model contributes to some positive outcomes that provide a protective barrier for OVC. The evaluation highlighted the importance of looking beyond the age of 18 years to sustain reduced vulnerability.

\section{References}

Allsopp, M. (2011). Raising children in a global village: Lessons from South Africa. Child and Youth Services, 32(2), 78-87. http://dx.doi.org/10.1080/0145935X.2011.581948

Betancourt, T. S., Meyers-Ohki, S. E., Charrow, A., \& Hansen, N. (2013). Research review: Mental health and resilience in HIVIAIDS-affected children: a review of the literature and recommendations for future research. Journal of Child Psychology and Psychiatry, 54(4), 423-444. doi: 10.1111/j.1469-7610.2012.02613.x

Brown, L., Thurman, T. R., Kalisa, E., Rice, J., de Dieu Bizimana, J., \& Boris, N., et al. (2007). Supporting volunteer mentors: Insights from a mentorship program for youth-headed households in Rwanda. Horizons Research summary. Washington: Population Council.

Chingwenya, A., Chuma, M., \& Nyanga, T. (2008). Trapped in the vicious circle: An Analysis of the sustainability of child-headed household's livelihoods in ward 30 Gutu District. Journal of Sustainable Development in Africa, 10, 264-286.

Cluver, L., \& Gardner, F. (2007). The mental health of children orphaned by AIDS: A review of international and Southern African research. Journal of Child and Adolescent Mental Health, 19(1), 1-17. doi: 10.2989/17280580709486631

Cluver, L., Gardner, F., \& Operario, D. (2007). Psychological distress amongst AIDS-orphaned children in urban South Africa. Journal of Child Psychology and Psychiatry, 48(8), 755-763. doi: 10.1111/j.1469-7610.2007.01757.x 
Cluver, L.D., Kganaka, M., Boyes, M.E., \& Park, M. (2012). Healthy minds: Psychosocial interventions for school-aged children affected by HIVIAIDS. In J. Heymann, L. Sherr, \& R. Kidman (Eds.), Protecting childhood in the AIDS pandemic: Finding solutions that work (pp. 119-143). New York: Oxford University Press.

Cluver, L., Orkin, M., Boyes, M., Gardner, F., \& Meinck F. (2011). Transactional sex amongst AIDSorphaned and AIDS-affected adolescents predicted by abuse and extreme poverty. JAIDS, 58(3), 336-343. doi: 10.1097/QAI.0b013e31822f0d82

Cluver, L., Orkin, M., Boyes, M. E., Sherr, L., Makasi, D., \& Nikelo, J. (2013). Pathways from parental AIDS to child psychological, educational and sexual risk: Developing an empirically-based interactive theoretical model. Social Science \& Medicine, 87, 185-193. doi: 10.1016/j.socscimed.2013.03.028

Cluver, L. D., Orkin, F.M., Boyes, M.E., \& Sherr, L. (2014). Cash plus care: social protection cumulatively mitigates HIV-risk behaviour among adolescents in South Africa. AIDS, 28(3), 389397.

Department of Education (2008). Implementation Guidelines for Safe and Caring Child-Friendly Schools in South Africa. Pretoria: DBE.

Department of Social Development. (2005). Policy framework for orphans and other children made vulnerable by HIV and AIDS South Africa. Pretoria: DSD.

Eloff, I., Finestone, M., Makin, J.D., Boeving-Allen, A., Visser, M., Ebersohn, L.,... Forsyth, B.W.C. (2014). A randomized clinical trial of an intervention to promote resilience in young children of HIVpositive mothers in South Africa. AIDS, 28(Supplement 3), S347-S357. doi: 10.1097/QAD.0000000000000335

Hewett, P. C., Mensch, B. S., \& Erulkar, A. (2003). The reporting of sensitive behavior by adolescents: A methodological experiment in Kenya. Demography, 40, 247-268. 
King, E., De Silva, M., Stein, A., \& Patel, V. (2009). Interventions for improving the psychosocial wellbeing of children affected by HIV and AIDS (Review). The Cochrane Library: Wiley \& Sons.

Mampane, M. R. (2010). The relationship between resilience and school: A case study of middleadolescents in township schools. Doctoral dissertation. Pretoria: University of Pretoria.

Meintjes, H., Hall, K., Marera, D., \& Boulle, A. (2010). Orphans of the AIDS epidemic? The extent nature and circumstances of child-headed households in South Africa. AIDS care, 22, 40-49. National Association for Child Care Workers. (2013). Retrieved from

http://www.naccw.org.za/isibindi.

Nyamukapa, C.A., Gregson, S., Wambe, M., Mushore, P., Lopman, B., Mupambireyi, Z., Nhongo, K., \& Jukes, M.C.H. (2010). Causes and consequences of psychological distress among orphans in eastern Zimbabwe. AIDS Care, 22(8), 988-996.

Nyberg, B. J., Yates, D. D., Lovich, R., Coulibaly-Traore, D., Sherr, L., Thurman, T.R, Sampson, A., \& Howard, B.H. (2012). Saving lives for a lifetime: Supporting orphans and vulnerable children impacted by HIVIAIDS. Journal of Acquired Immune Deficiency Syndrome, 60, S127-S135. doi: 10.1097/QAI.0b013e31825da836

Reddy, P., James, S., Mutumba Bilay-Boon, H., Williams, E., \& Khan, H. (2009). A pilot communitybased intervention program to address the needs of elderly caregivers in the Eastern Cape Province of South Africa. Horizons Research Summary. Washington: Population Council.

Richter, L., Sherr, L., Adato, M., Belsey, M., Chandan, U., \& Desmond C, et al. (2009). Strengthening Families to Support Children Affected by HIV and AIDS. AIDS Care, 21(1), 3-12. doi: $10.1080 / 09540120902923121$

Rotheram-Borus, M. J., Stein, J.A. \& Lester, P. (2006). Adolescent adjustment over six years in HIVaffected families. Journal of Adolescent Health, 39, 174-182. doi: 10.1016/j.jadohealth.2006.02.014 
Schenk, K. D. (2009). Community interventions providing care and support to orphans and vulnerable children: a review of evaluation evidence. AIDS Care, 21, 918-942. doi: $10.1080 / 09540120802537831$

Schenk, K. D., Michaelis, A., Sapiano, T. N., Brown, L., \& Weiss, E. (2010). Improving the lives of vulnerable children: Implications of Horizons research among orphans and other children affected by AIDS. Public health reports, 125, 325-336.

Schenk, K., Ndhlovu, L., Tembo, S., Nsune, A., Nkhata, C., \& Walusiku B. (2008). Supporting orphans and vulnerable children affected by AIDS: Using community-generated definitions to explore patterns of children's vulnerability in Zambia. AIDS Care, 20, 894-903. doi:

$10.1080 / 09540120701767232$.

Scott, K.J. (2009). A community-based model of supervision for child and youth care workers employed in the ISIBINDI model of care in South Africa. Unpublished dissertation in Social Work. Pretoria: University of South Africa. URI: http://hdl.handle.net/10500/4056

Setswe G., \& Skinner, D. (2008). Interventions for orphans and vulnerable children at four project sites in South Africa. Cape Town: Human Sciences Research Council.

Sherr, L., Cluver, L.D., Betancourt, T.S., Kellerman, S.E., Richter, L.M. \& Desmond, C. (2014). Evidence of impact: health, psychological and social effects of adult HIV on children. AIDS, 28(3), S251-S259. doi: 10.1097/QAD.0000000000000327

Shisana, O., Simbayi, L. C., Rehle, T., Zungu, N.P., Zuma, K., \& Ngongo N, SABSSM III Implementation Team. (2010). South Africa national HIV prevalence, incidence, behaviour and communication survey, 2008. The health of our children. Cape Town: HSRC Press.

Thurman, T. R., Brown, L., Richter, L., Maharaj, P., \& Magnani, R. (2006). Sexual risk behavior among South African adolescents: Is orphan status a factor? AIDS and Behaviour, 10(6), 627-635. doi: 10.1007/s10461-006-9104-8. 
Thurman, T.R., Kidman, R., Taylor, T.M., \& Chiroro, P. (2013). Isibindi: A longitudinal evaluation of selected sites in KwaZulu-Natal. New Orleans, Louisiana: Tulane University. New Orleans, Louisiana: Tulane University.

Thurman, T.R., Kidman, R., \& Taylor, T.M. (2014) Does investment in home visitors lead to better psychological health for HIV-affected families? Results from a quasi-experimental evaluation in South Africa. AIDS Care: Psychological and Socio-medical Aspects of AIDS/HIV, 26:sup1, S2-S10, DOI: $10.1080 / 09540121.2014 .906555$

United Nations Children's Fund (UNICEF) (2004). The framework for the protection, care and support of orphans and vulnerable children living in a world with HIV and AIDS. New York: UNICEF.

U.S. President's Emergency Plan for AIDS Relief. (2012). Guidance for orphans and vulnerable children programming. PEPFAR.

Watts, H., Gregson, S., Saito, S., Lopman, B., Beasley, M., \& Monasch, R. (2007). Poor health and nutritional outcomes in orphans and vulnerable young children not explained by greater exposure to extreme poverty in Zimbabwe. Tropical Medicine and International Health, 12, 584-593.

Wood, L., \& Goba, L. (2011). Care and support of orphaned and vulnerable children at school: helping teachers to respond. South African Journal of Education, 31, 275-290. 